\title{
Effectiveness of educational virtual class during Covid-19- with reference of Music online class of Fine Arts Campus, TU
}

\author{
Parsuram Prasad Poudel ${ }^{1 *}$
}

${ }^{1}$ Lecturer in Music (Tabla) at Lalitkala Campus, Tribhuvan University

*Corresponding Author: parsuram.poudel@gmail.com

Citation: Poudel, P. P. (2021). Effectiveness of educational virtual class during Covid-19- with reference of Music online class of Fine Arts Campus, TU. Journal of Fine Arts Campus, 3(1), 6-14.

Abstract: As the Covid19 pandemic started, COVID infected nations announced to keep physical distance, affected all the human activities, as a result, educational institutions closed physically. The aim of the present research was to study the effectiveness of virtual class during Covid-19 with reference to music online class of Fine Arts Campus, TU. An online survey design was used by taking responses of 47 students of the Bachelors' program and further corresponded with 16 teachers, and 17 parents for the data collection through Google Form. The finding of the research indicates that the online mode of the educational class, with reference to practical and theory music subjects, was ineffective for students and effective for teachers and parents.

Keywords: Covid19, effectiveness, virtual class, music learning, Nepal. Introduction:

Education is an indispensable subject for human life at any time. Without education all the activities of human beings are ever affected. Education is an ultimate means to achieve success and prosperity in human life. An educated person only can serve the country and society with discretion and responsibility. In oxford learner's dictionary, a process of teaching, training and learning, especially in schools, colleges or universities, to improve knowledge and develop skills is education (Oxford Dictionary, 2021). Human civilization has been developing along with education since the evolution of human beings. Civilization always stands parallel with education. So, education is a basic need as food, shelter, cloth, these days. Education is, therefore, also considered as the bedrock of the socio-economic, cultural and political uplift of a society or a country (Bordoloi, 2018). During the course of educating people, many critical situations has been created, around the world.

According to WHO, one of the problematic and critical situations has been spreading worldwide is Covid19, which was firstly identified on 31 Dec 2019. COVID-19 (Coronavirus Disease- 2019) is a kind of communicating and infectious disease, which spreads primarily through droplets of saliva or discharge from the nose when an infected person coughs or sneezes (Mythbusters, 2020). Gradually this virus spreads all over the world, creating an epidemic into pandemic situation (Ouassou et al., 2020). Numbers of patients increased in multiplication mode, made scarcity of medical services, even in developed countries. 33 countries got high-infection during early 2020 . WHO announced March 11, 2020 as Corona Pandemic Day (Archived: WHO Timeline - COVID-19, 2020). There are more than 2 million documented cases of COVID-19 worldwide and nearly 200,000 deaths (Dimaio et al., 2020). Schools, colleges and universities closed for uncertain time durations. Students and staffs stayed at home. As the government of each state cancelled their major programs, Nepal also announced lockdown from 24 Mar 2020 (www.garda.com, 2020), called off the Visit Nepal 2020 campaign (Prasain,2020) and other developmental activities. The several impacts like social, economic, healthcare, psychological, educational and other were found during the lockdown in Nepal. A panic situation began in the states due to an unexpected lockdown announced by governments (Pacey, 2020).

Based on the circular forwarded by the ministry of education, science and technology, Tribhuvan University also decided to close its educational classes for uncertain time periods. Further, notification was given to all its colleges to continue the course through online medium. As the circular by TU, Fine Arts Campus (www.factu.edu.np,2021) also remained closed except administration and acted for the necessary arrangements for the virtual classes. For the purpose of online class, TU managed Microsoft Teams accounts for each student, teacher and staff separately with the purpose to conduct virtual classes. For the support, ICT (information and communication technology) staff was appointed, several online trainings were organized and an amount of budget was released to each campus for necessary arrangements.

\section{Research Objective}

Tribhuvan University is the largest and oldest university in Nepal. It has also officially endorsed the virtual class model along with a guideline and circulated a notice among its institutions, Fine Arts Campus also arranged for online class to continue the educational session. The main objective of present study is to examine the effectiveness of Virtual Class during COVID 19, in Fine Arts Campus Bachelors in Fine Arts (BFA). Do all students have access to the quality internet to attend the classes without disturbance? Are the teachers and students well equipped and trained enough to run the virtual classes effectively? Do teachers and students have enough habit to read digital texts? Moreover, are all the students be able to use this opportunity of distance learning? What the parents think about? And what about the other unseen problematic issues exist, are the research questions to answer. 


\section{Methods}

The cross-sectional survey design was used in the research. Online survey design through Google Form was used to collect the information through the concerned stakeholders (students, parents and teachers). The link of Google Form was shared through the Facebook, email and Microsoft Teams for data collection as guidelines provided by senior researchers. The contact information of students, parents and teachers were taken by the administration of Fine Arts Campus, Tribhuvan University (TU), and Nepal. The 47 students, 16 teachers and 17 parents participated in the survey with their response through the link.

\section{Research instrument}

For the collection of data from the respondents, self-constructed three questionnaires were raised toward the students, teachers and parents, separately. From the questionnaires, the views of respondents were collected.

\section{Data analysis technique}

This study is based on quantitative analysis. The numerical findings from the responses are presented through the tables, figures, based upon the questionnaires, are the source of data to analyze.

\section{Presentation and interpretation of data}

The respondents for this article are students, teachers and parents associated with the online music class of BFA. After the announcement of lockdown, the only one medium to communicate with concerned seemed to be online mode. As a study carried out, three-quarters of the respondents feel that concerned academic authorities should officially initiate online classes regularly at the bachelor's level(Heyojoo et al., 2021), the students, teachers and parents of Lalitkala Campus also showed their tendency to connect with through online technology. The study had collected the demographic characteristics of students, teachers and parents like gender, location, and experience of online class, internet channel, regularity, teaching methods, devices and others to know the distribution of respondents participated in the study. The collected data are presented in the following tables:

Table 1 Response of students including socio-demographic characteristics $(n=47)$

\begin{tabular}{|c|c|c|c|}
\hline Variables & Frequency $(\%)$ & Variables & Frequency $(\%)$ \\
\hline Gender & & Educational Qualification & \\
\hline Male & $37(78.72)$ & $10+2$ & $45(95.74)$ \\
\hline Female & $10(21.28)$ & Masters & $2(4.26)$ \\
\hline Bachelors Level & & Your occupation/profession & \\
\hline First year & $15(31.91)$ & Students & $42(89.36)$ \\
\hline Second year & $13(27.66)$ & Office Staff & $2(4.26)$ \\
\hline Third year & $10(21.28)$ & Business & $3(6.38)$ \\
\hline Fourth year & $9(19.15)$ & Device used & \\
\hline Internet Connection & & Mobile & $41(87.23)$ \\
\hline $\mathrm{Wi}-\mathrm{Fi}$ & $39(82.98)$ & Laptop & $4(8.51)$ \\
\hline Private & $26(55.32)$ & Desktop/Other & $2(04.26)$ \\
\hline Shared & $21(44.68)$ & Problem during online class & \\
\hline Mobile Data & $8(17.02)$ & Network Lost & $26(55.32)$ \\
\hline Educational Materials you got & & Unclear Audio & $18(38.30)$ \\
\hline Written notes & $8(17.02)$ & Unclear Video/Device Problem & $3(6.38)$ \\
\hline Oral Direction & $19(40.43)$ & Regularity in virtual class: & \\
\hline Both & $9(19.15)$ & Yes & $26(55.32)$ \\
\hline No thing & $11(23.40)$ & No & $7(14.89)$ \\
\hline $\begin{array}{l}\text { Submission of theory exam after online } \\
\text { class was: }\end{array}$ & & Sometimes & $14(29.79)$ \\
\hline Harder & $23(48.94)$ & Which is better? & \\
\hline Good & $19(40.43)$ & Theory subject & \\
\hline Best & $5(10.64)$ & Physical & $32(68.09)$ \\
\hline $\begin{array}{l}\text { Preference about online class with } \\
\text { practical music class }\end{array}$ & & Virtual & $2(4.26)$ \\
\hline Physical Class & 45(95.74) & Both & $13(27.66)$ \\
\hline \multirow[t]{3}{*}{ Virtual Class } & $2(4.26)$ & Practical subject & \\
\hline & & Physical & $39(82.98)$ \\
\hline & & $\begin{array}{l}\text { Virtual } \\
\text { Both }\end{array}$ & $\begin{array}{l}2(4.26) \\
6(12.76)\end{array}$ \\
\hline
\end{tabular}




\section{Responses of students towards online learning}

The above data shows that in total majority of the students were male (78.72\%) followed by female $(21.28 \%)$. $95.75 \%$ of the students are from $10+2$ education and $4.75 \%$ have already completed master's degree from other subjects. This shows their interest in music however they have already completed master's degree. In this survey, $31.91 \%, 27.66 \%, 21.28 \%$ and $19.15 \%$ are the respondents represented from BFA 1st, 2nd, 3rd and 4th year respectively. Job holders (Office staff $4.25 \%$ and $6.38 \%$ ) have also shown their deep interest in music learning and admitted in BFA. During the virtual class, $82.98 \%$ of the students connected through Wi-Fi and $17.02 \%$ connected through mobile data. Those connecting through mobile data either have no capacity to connect through Wi-Fi or they are connecting from remote area. Most of the students (80.85\%) used their mobile and $8.51 \%$ and $10.64 \%$ used laptop and desktop. Thus, ratio between mobile users and computer user is approximately 10:1. 40.4\% of the total virtual classes were orally carried out, $17 \%$ students got written notes, $19 \%$ got oral and written matters and $23.4 \%$ students got nothing, which means either the effectiveness of online classes didn't get attention of students or teachers just taught just simply, during online class. 55.32\% of the students felt difficulty for connecting online class due to network loss problem. Likewise, $38.3 \%$ student respondent felt unclear audio and rest confronted with visual difficulty.

Similarly, students were asked about their final paper-based theory submission after the virtual class as per the routine by Tribhuvan University. Approximately, $1 / 2$ of the students felt harder in examination, $40.42 \%$ of the students felt average and only few students $10.64 \%$ students gave their best performance. Only $55.32 \%$ students took online class regularly, $29.79 \%$ students got presence sometimes, which shows their less interest for virtual music class. $14.89 \%$ never attended the virtual class. Very large population of the student respondent, which is $95.74 \%$, voted for physical class due to many problems in online music class. Only few students $4.26 \%$ voted for online class. At last, students were asked to choose for virtual channel for theory vs practical class. Just $8.93 \%$ of the students voted for physical class in reference with both, theory and practical class of music in BFA.

Table 2 Response of teachers including socio-demographic characteristics $(n=16)$

\begin{tabular}{|c|c|c|c|}
\hline Variables & Frequency $(\%)$ & Variables & Frequency $(\%)$ \\
\hline Gender & & Educational Qualification & \\
\hline Male & $12(75)$ & Masters & $12(75)$ \\
\hline Female & $4(25)$ & Above Masters & $4(25)$ \\
\hline Teaching as: & & Masters in another subject & $7(43.75)$ \\
\hline Profession & $14(87.5)$ & Internet Connection & \\
\hline \multirow[t]{2}{*}{ Hobby } & $2(12.5)$ & Wi-Fi private & $9(56.3)$ \\
\hline & & Wi-Fi shared & $7(43.75)$ \\
\hline Device used & & Educational Materials you provided & \\
\hline Mobile & $2(12.5)$ & Written notes & $2(12.5)$ \\
\hline Laptop & $12(75)$ & Oral Direction & $3(18.75)$ \\
\hline Desktop/Other & $2(12.5)$ & Audio-visual & $2(12.5)$ \\
\hline Online class training: & & All & $9(56.3)$ \\
\hline Trained by college & $10(62.5)$ & Problem during online class: & \\
\hline Trained by media & $4(25)$ & Network Lost & 13(81.25) \\
\hline Trained by colleagues & $2(12.5)$ & Unclear Audio & $1(6.25)$ \\
\hline Regularity in virtual class: & & Unclear Video & $2(12.5)$ \\
\hline Yes & $16(100)$ & Which class was better? & \\
\hline How much are you success & & Theory & $12(75)$ \\
\hline Perfect/Success & $9(56.25)$ & Practical & $4(25)$ \\
\hline Average/Somehow & $7(43.75)$ & Students' interest on online class & \\
\hline $\begin{array}{l}\text { Necessity of Virtual class during } \\
\text { lockdown }\end{array}$ & & Yes & $2(12.5)$ \\
\hline Strongly Disagree & $1(6.25)$ & May be & $7(43.75)$ \\
\hline Disagree & $0(0)$ & No & $5(31.25)$ \\
\hline Neutral & $5(31.25)$ & Not at all & $2(12.5)$ \\
\hline Agree & $6(37.5)$ & & \\
\hline Strongly agree & $4(25)$ & & \\
\hline
\end{tabular}

Responses of teachers towards online learning 
As teachers are another important respondent of this study, 25\% were female and $75 \%$ were male teachers. Among them $3 / 4$ have completed master's degree on musical subject and $1 / 4$ have been in above master's level in music. $87.5 \%$ teachers follow music teaching as their profession and surprisingly $12.5 \%$ has taken music teaching as hobby. As all the teachers use to connect through Wi-Fi and above $3 / 4$ of the teacher faced network loss during class. As far as about teachers' regularity, they were $100 \%$ regular in their virtual music class as their responses came. $5 / 8$ teachers said that they were given certain training by college about the virtual class to conduct. But $3 / 8$ teachers learnt from others about virtual class procedure. Only $56.25 \%$ teacher got satisfied from online class but near to $1 / 2$ of the teachers such as $44.75 \%$ teachers expressed that their online classes were somehow success. This shows that virtual classes are somehow applicable, not for all the subjects. $3 / 4$ of the teachers voted virtual online classes and vice versa. Near to $1 / 2$ of the teachers felt that the students were not sure to attend the classes. $31.25 \%$ of teachers got neutral the arrangement of virtual music class where as $37.5 \%$ teachers agree to connect on online class. In the other side, $1 / 4$ of the teachers urged for the conduction of online class during lockdown, to continue the educational activities in BFA. During the virtual class, $56.25 \%$ teachers used mixed type of educational materials whereas only $12.5 \%$ provided written notes to students and rest conducted orally.

Table 3 Response of parents $(n=17)$

\begin{tabular}{llll}
\hline Variables & Frequency $(\%)$ & \multicolumn{1}{c}{ Variables } & Frequency $(\%)$ \\
\hline Regularity of virtual class: & & Regularity of your children: & $12(70.59)$ \\
Yes & $10(58.82)$ & Yes & $5(29.41)$ \\
No & $7(41.18)$ & No & $4(23.53)$ \\
Preferred by your children & & Children's interest on online class & \\
Physical & $14(82.35)$ & Most Interested & $99(52.94)$ \\
Online & $3(17.65)$ & Average & $4(23.53)$ \\
Which class is better? & & Less & \\
Physical & $16(94.11)$ & & \\
Online & $1(5.89)$ & &
\end{tabular}

\section{Responses of parents towards online learning}

The respondents generally had favorable attitudes toward online college degree programs (Sunho \& Junior, 2021), a study found, but the present research found that $94.11 \%$ parents had favorable attitude toward physical class. As 5 important questions were asked to parents whose children had been in online class during lockdown, $58.82 \%$ of the parent said that the regularity of online classes used to conduct in right time but $41.18 \%$ told negative response. $70.59 \%$ parents found their children regular in online class and vice versa. As per the parents, $82.35 \%$ children like physical class, likely, $94.11 \%$ of the parents vote for physical class.

Table 4 Comparative study of same variables among student, teachers and parents.

\begin{tabular}{lccc}
\hline Questions & Students & Teachers & Parents \\
\hline How was the regularity of you? & & & \\
Everyday & $55.32 \%$ & $100 \%$ & $70.59 \%$ \\
Sometimes & $14.89 \%$ & & \\
Never & $29.79 \%$ & & $29.41 \%$ \\
children's interest on virtual class & & & $23.53 \%$ \\
Deep & & & $52.94 \%$ \\
Average & $51.25 \%$ & $72.23 \%$ & $23.53 \%$ \\
Least & $49.75 \%$ & $27.77 \%$ & \\
Is the 'network lost' as common problem? & $55.32 \%$ & $81.25 \%$ & \\
Which subject do you prefer in virtual mode of class? & & & \\
Theory & $4.26 \%$ & $75 \%$ & \\
Practical & $4.26 \%$ & $25 \%$ & \\
Which mode of class do you prefer mostly? & & & \\
Virtual class & $4.25 \%$ & $93.75 \%$ & $94.18 \%$ \\
Physical class & $95.75 \%$ & $6.25 \%$ & $5.82 \%$ \\
Why virtual class is ineffective? (Based on conversation) & & & \\
Internet problem & $5.67 \%$ & $89.44 \%$ & \\
Virtual class in not suitable for practical music class & $94.33 \%$ & $10.56 \%$ & \\
\hline
\end{tabular}

Discussion and Results: 
The popularity of online classes in recent years leads to an increased number of online course offerings through distance education by schools and colleges. Online classes are then success if the internet facility is perfect. The bandwidth provided by the internet company determines the speed of internet to each customer. A study concurs that distance education can be just as good as traditional face-to-face education (Tucker \& Shelia, 2001). There are over 7.5 million students from the school to university levels. A recent report of Nepal Telecommunications Authority shows that about 72 percent of the people are connected to the internet, and an overwhelming number of them rely on mobile data to access the internet. Only around 12 percent of the people have broadband internet connection (Ghimire, 2020). Another study states that, it can be assumed that online education may be the pedagogies strategies for the time of lockdown (Al-Dheleai, 2021). Some discussions are made as per the followed figures.

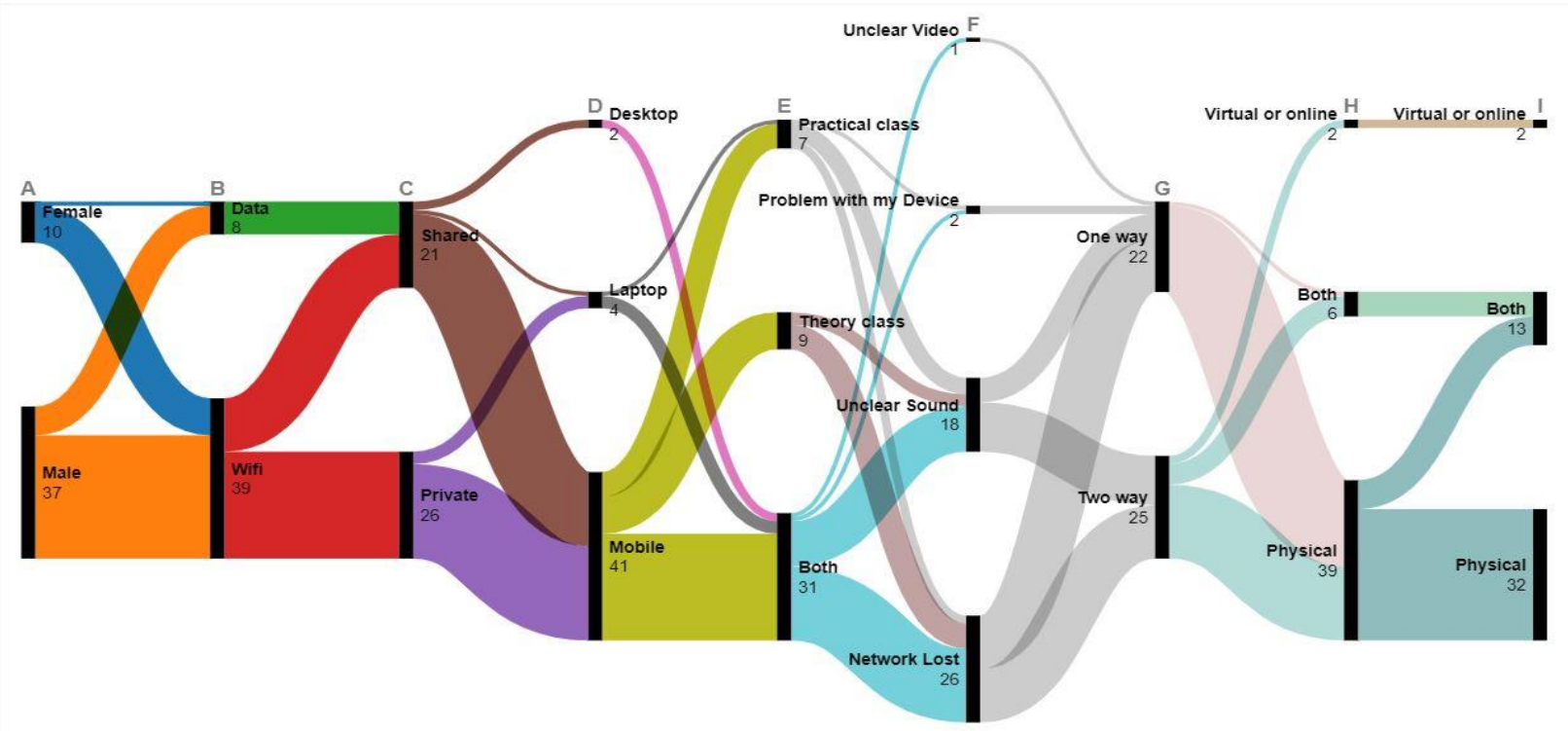

Figure 1 Overall responses from the students

A - Gender $\quad$ B - Internet connection for online class $\quad$ - Availability of Internet

D-Device used E-Students attended online for theory or practical or both $\mathrm{F}$ - Technical problems

G-Communication H-Students' preference for practical music class I - Students' preference for theory music class.

The presented figure 5 represents nine specific questions asked to students about their overall online classes. Among the 47 students $78.72 \%$ were male students. This shows somehow less female participation in music education. Probably the students from remote area of financially weak, $17.02 \%$ students were found connecting through mobile data, which is of less bandwidth but no needs special arrangements. $82.98 \%$ students seemed probably from town area where internet facilities are more. Approximately, half of the students could afford private Wi-Fi. Mobile users were found more than $87 \%$, a few students could afford desktop and laptop for the purpose of education. In comparison of mobile, the laptop or the desktop is more advantageous and multifunctional for joining the online classes. Learning is not easier through just the conversation or audio-visual process as in mobile, but also needs to create the learning environment between the teachers and students. That's why the students could not get the lessons properly. Their performance during the theory examinations seemed harder to them, as $48.94 \%$ of the students stated. Through the online mode, near to $66 \%$ students attended both - theory and practical class. The problem of network discontinue is higher, represented by $55 \%$ students and weak internet connection leaded unclear audio and video, according to the responses given. Nearly, half of the students could get communicate and share the views and ideas with their teachers, points out that the teachers were applying students oriented pedagogy during teaching. As per the responses from the students, $83 \%$ of the students preferred physical class for practical music class and $68 \%$ of the students preferred wanted physical class for theory too. Very few students found standing for online mode for both theory and practical music class. Some reasons behind this result might be, lack of student-oriented teaching methods, lack of music and internet-friendly devices, lack of reading notes to students, no interactive as well as participatory activities, fewer facilities, weak monitoring system, and course taught is not a web-based course, alike a study published before (Mama-Timotheou, 2015). Another cause that negatively affected the online class was that there was no online training 
to the students. Students, new to online learning, also may not be as adapted to the idea of student-to-student interaction, or self-initiated learning that is facilitated by the instructor (Fedynich et al., 2015). The cost dealt for the virtual class on behalf of students and parents might be another major factor (Jones \& Blankenship, 2015). The students from European and Asian has significance difference in the perception for the online mode, a study concludes too (Chew \& Yee, 2011). This scenario clearly shows, less interest and less responsible, on behalf of students, toward the online classes conducted by campus.

Figure 2 Presence of students during online class

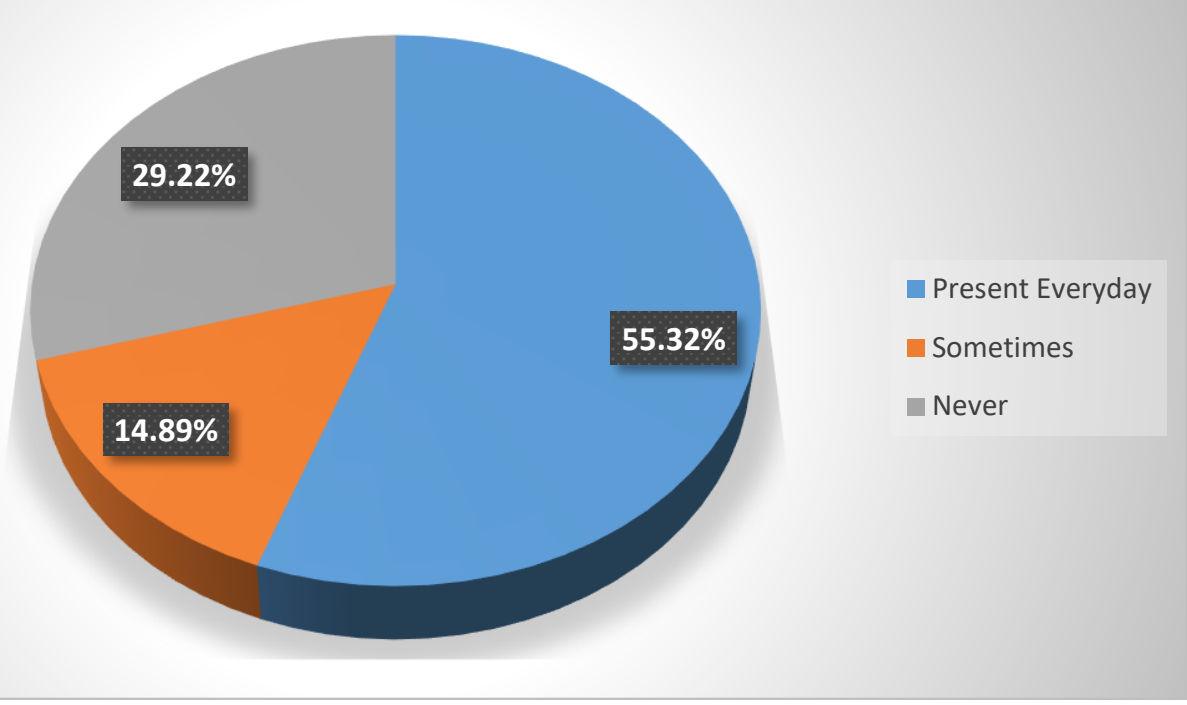

The absence rate of students in their class is also disappointing fact. Students were not found interested in online classes. The students are ever expected to participate themselves in three main categories; course activities, interactions with instructors, and interactions with other students (Mortagy \& Boghikian-Whitby, 2010). But in case of Fine Arts Campus, it was disappointing factor. However, in the early days, students were joining it, but now that the summer vacation has been declared, the trend of students has become extremely low (Vijaya, 2020). Alike above, in a conversation with one of the teachers, involved in online classes that his students of BFA $2^{\text {nd }}$ year and $3^{\text {rd }}$ year rarely presented in the scheduled classes. "When our college arranged the online firstly, Zoom was the main medium to conduct classes, students used to present over $90 \%$, but later, less than $15 \%$ of the concerned students connected with me during online class, which was disappointing matters to me" one teacher said. Some of the teachers found satisfied with the presence of students during their classes. But, in overall, according to this study, just $55.32 \%$ of the students got present in class where as $29.79 \%$ never entered in online class (Figure-2). These absent students either didn't have access to internet or living in remote area or they had just habit to ignore classes as other drop out students of government colleges do commonly. A study (Raval, 2020) shows that $49 \%$ of the respondents did not go online for academic purpose during lockdown. The students usually face some difficulties during Covid19 lockdown. Adopting the technology for the first time in their classes, online classes comparatively less interactive than physical class, poor and expensive internet connectivity as well as lack of suitable device are some problems for the students (Khati \& Bhatta, 2020). More than those, lack of educational environment, expensive and black market of learning devices, electricity unavailability, remoteness and many more are the drawbacks of virtual classes.

For teachers, the problem arose because they neither expected nor prepared for online classes during lockdown. Learning technology was great challenge for teachers. The teachers were not habitual to read digital texts before (Laeli et al., 2020). Also, the lack of eye contact makes it difficult for them to understand whether students are getting their pace or not. For some teachers, their children at home often disturb synchronous class delivery (Khati \& Bhatta, 2020). Likewise, teachers were also the victim of some common problems as well. "In the one side, untimely and less remuneration system has disturbed our livelihood regularly and in the other side we have more attention to be saved from COVID 19 than the other necessities to fulfill", one of the part time teachers expressed during conservation. It was more difficult to those teachers, who have their own children to care whole day during COVID 19 lockdown. Due to unavailability of a greater number of learning devices (laptop, computer, mobile) and library for teachers and for their studying children at the same time of online class routine is another headache for the parenting teachers (Figure 1).

Parents has another challenge to maintain their family during all the situations. COVID 19 has been influencing everyone's life since it's emerged. In the name of online class, parents always find their child hanging on 
devices. Not only the uneducated parents, even educated parents also get confused about the routine of online classes for their children during the morning, day, and evening time. Conscious parents, always get worried about their children's activities in internet. "I am ever concerned that my children may develop bad habits due to misguided use of the Internet," one of the parents told.

During the COVID19 infection, patient need to confine him/herself to cut the chain of Corona virus (Siobhan, 2020). Some of the effects analyzed in people under confinement due to infection of Corona found confusion, anger, fear, frustration, boredom or post-traumatic stress symptoms. This problematic situation causes an increase in negative emotions, such as anxiety, depression and indignation, and of sensitivity to social risks, while decreases are reported in positive emotions such as happiness and life satisfaction (Cabedo-Mas et al., 2021). So, in my opinion, keeping one's hand, heart and mind busy in some creative activity such as music listening and learning automatically divert the patient's psychological state, fruitfully. As, for many years music has been used as a tool to increase psychological wellbeing in people experiencing situations of isolation or confinement (Van de Wall, 1924), the music students of BFA are also not so far from this positive result, directly-indirectly.

Figure 3 Which mode of class do you prefer mostly?

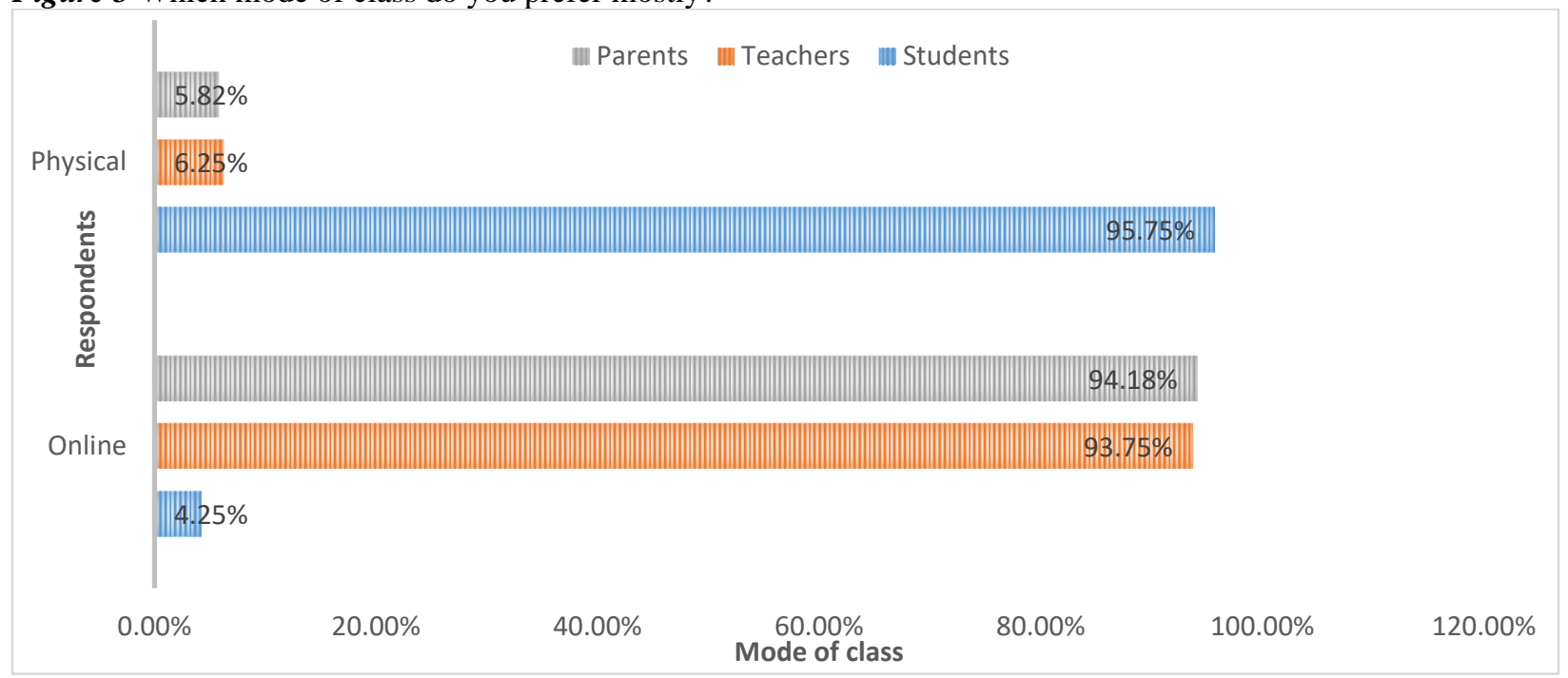

The above, Figure 3, explains about the interestedness and preference given to online or physical classes by teachers, student and parents. Parents and teachers have less preference in physical class. One of the parents told the reason behind that was the most of the parents usually don't want their children to gather physically during the pandemic. They want to protect children from infection, naturally. Likewise, teachers too intend to follow physical distance, whereas, probably, the students seem to have less consciousness about the importance of physical distance during pandemic situation. The students/children tend to meet each other physically rather than virtually.

Figure 4 Why virtual class is ineffective? (Based on conversation)

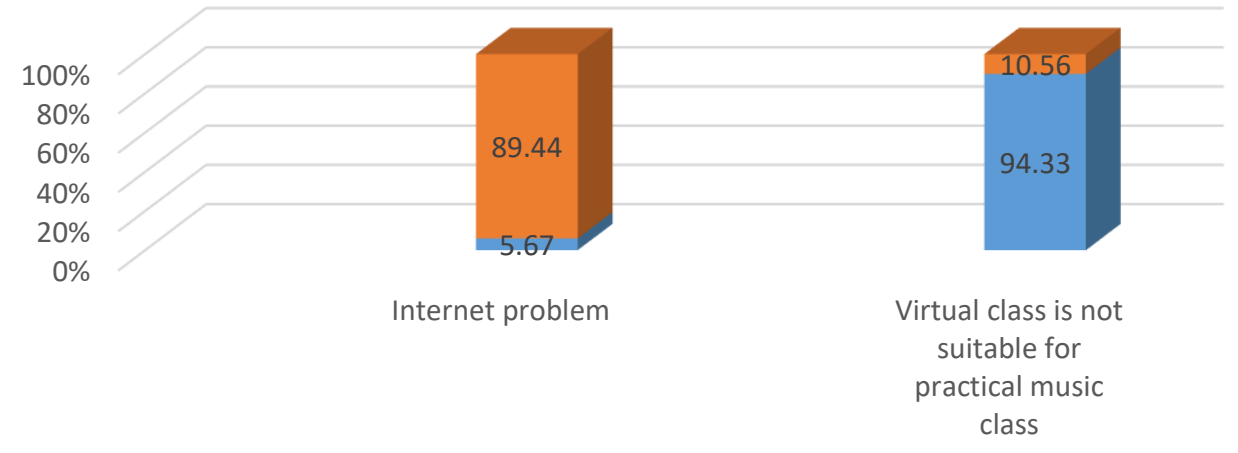

Students $\quad$ Teachers

Figure 4, elaborates that the intention about online classes between the group of students and teachers of Fine Arts Campus inverse with each other. Here, $89.44 \%$ teachers point out the internet problem as main cause for the 
ineffectiveness of online class whereas $94.33 \%$ of the students point out that online mode for practical music class is not suitable at all.

\section{Summery}

This study was limited just amongst the students, teachers and parents representing from Fine Arts Campus. The responses may vary due to the nature of subjects taught here, which are mostly practice based. Despite the limitations discussed above, this government college somehow has managed to conduct firstly the practical and theoretical classes of music through an online version, which in an example among other colleges in Nepal. It is found that most of the students of BFA has tendency to be absent in online class for practical as well as theoretical music classes. Therefore, there is a big question that why most of the students get less involved in online classes, which needs to be researched and managed more, on behalf of the Fine Arts Campus, in the future. The reason behind this is found that lacking the internet availability, lack of e-learning habit, cheapest fee structure and others. Similarly, the teachers and students were not trained enough to carry virtual classes before the lockdown. The necessary equipment and devices play vital role in online mode of every class, but lacking those essential arrangements were another drawback on behalf of students, teachers and parents. The current syllabus, been taught to students, found lacking of digital texts and virtual methodologies but rich in the traditional methodologies. So, during the lockdown, most of the students were not able to utilize their time to attend the online classes. In fact, to overcome upon those drawbacks, the management part of the college is highly recommended to be more practical and result-oriented than before, to make effective online learning during coming possible pandemic days, in future.

\section{References}

Al-Dheleai, Y. (2021). Education continuation strategies during COVID-19 in Malaysia. International Journal of Academic Research in Business and Social Sciences, 11(4). https://doi.org/10.6007/IJARBSS/v11-i4/9840

Archived: WHO Timeline - COVID-19. (2020). https://www.who.int/news/item/27-04-2020-who-timeline---covid19

Bordoloi, R. (2018). Transforming and empowering higher education through Open and distance learning in India. Asian Association of Open Universities Journal, 13(1), 24-36. https://doi.org/10.1108/AAOUJ-11-2017-0037

Cabedo-Mas, A., Arriaga-Sanz, C., \& Moliner-Miravet, L. (2021). Uses and perceptions of music in times of COVID-19: A Spanish Population Survey. Frontiers in Psychology, 11, 3928. https://doi.org/10.3389/fpsyg.2020.606180

Chew, R., \& Yee, S. (2011). Perceptions of online learning in an australian university: Malaysian students' perspectives. http://www.ijiet.org/papers/573-I012.pdf

Dimaio, D., Enquist, L. W., \& Dermody, T. S. (2020). A new coronavirus emerges, this time causing a pandemic. Annual Review of Virology, 7, iii-v. https://doi.org/10.1146/annurev-vi-07-042020-100001

Fedynich, L., Bradley, K. S., \& Bradley, J. (2015). Graduate students' perceptions of online learning. Research in Higher Education Journal, 27. http://www.aabri.com/copyright.html.

Fine Arts Campus. (2021). http://factu.edu.np/

Ghimire, B. (2020). Digital divide too wide for online classes to succeed in Nepal. Https://Kathmandupost.Com/. https://kathmandupost.com/national/2020/05/28/government-has-proposed-conducting-online-classes-but-amajority-of-schools-and-students-don-t-have-computers-and-internet

Heyojoo, B. P., Bhattarai, S., \& Subedi, R. (2021). Effectiveness of online classes in Nepal. In https://english.onlinekhabar.com/effectiveness-of-online-classes-in-nepal-what-three-teachers-felt-after-anexperiment.html

Simon, J. C., Brooks, L. D., \& Wilkes, R. B. (2011). Students' perceptions of online courses. Online and Distance Learning, 32, 1537-1545. https://doi.org/10.4018/978-1-59904-935-9.ch124

Khati, K., \& Bhatta, K. (2020). Challenges of online education during COVID-19 pandemic in Nepal. International Journal of Entrepreneurship and Economic Issues, 4(1), 45-49. https://doi.org/10.32674/ijeei.v4i1.45

Laeli, A. F., Setiawan, S., \& Anam, S. (2020). Reading digital text as a new literacy in elt: teachers' perception \& practices. ETERNAL (English, Teaching, Learning, and Research Journal), 6(2), 312. https://doi.org/10.24252/eternal.v62.2020.a9

Mama-Timotheou, M. (2015). Differentiation of student perceptions for online courses, over time. Lecture Notes in Computer Science (Including Subseries Lecture Notes in Artificial Intelligence and Lecture Notes in Bioinformatics), 9192, 697-703. https://doi.org/10.1007/978-3-319-20609-7_65

Mortagy, Y., \& Boghikian-Whitby, S. (2010). A longitudinal comparative study of student perceptions in online education. Interdisciplinary Journal of E-Skills and Lifelong Learning, 6, 23-44. https://doi.org/https://doi.org/10.28945/1128

Mythbusters. (2020). https://www.who.int/emergencies/diseases/novel-coronavirus-2019/advice-for-public/myth- 
busters

Ouassou, H., Kharchoufa, L., Bouhrim, M., Daoudi, N. E., Imtara, H., Bencheikh, N., Elbouzidi, A., \& Bnouham, M. (2020). The pathogenesis of coronavirus disease 2019 (COVID-19): Evaluation and prevention. In Journal of Immunology Research (Vol. 2020, pp. 1-7). Hindawi Limited. https://doi.org/10.1155/2020/1357983

Oxford Dictionary. (2021). https://www.lexico.com/en/definition/music

Pacey, A. A. (2020). Lockdown. In Human Fertility (Vol. 23, Issue 1, p. 1). Taylor and Francis Ltd. https://doi.org/10.1080/14647273.2020.1752460

Prasain, S. (2020). Visit Nepal 2020 called off, finally. The Kathmandu Post. https://kathmandupost.com/national/2020/03/31/visit-nepal-2020-called-off-finally

Raval, C. (2020). A Sociological View of social Impact of Social Distancing and Lockdown. Vidya A Jpurnal, 1(1). https://vidya.gujaratuniversity.ac.in/Uploads/EJournalDetail/1/1/(13-23) A Sociological View of social Impact of Social Distancing and Lockdown.pdf

Siobhan, R. (2020). You Can Help Break the Chain of Transmission. The New York Times. https://www.nytimes.com/2020/03/19/health/coronavirus-distancing-transmission.html

Sunho, K., \& Junior, P. (2021). Parents' Perception of Online College Degree Programs for their Children. jisc.org

Tucker, \& Shelia. (2001). Distance Education: Better, Worse, Or As Good As Traditional Education? Online Journal of Distance Learning Administration, 4(4). https://www.westga.edu/ distance/ojdla/winter44/tucker44.html

Van de Wall, W. (1924). The utilization of music in prisons and mental hospitals. Colorado State University, Fort Collins.

Vijaya, P. (2020). Why online classes may not be such a good idea after all especially for kids.

Https://Www.Livehindustan.Com/. https://www.livehindustan.com/career/story-online-education-why-onlineclasses-may-not-be-such-a-good-idea-after-all-especially-for-kids-3247511.html

www.garda.com. (2020). https://www.garda.com/crisis24/news-alerts/326601/nepal-government-announcesnationwide-lockdown-from-march-24-31-update-4

WHO Timeline - COVID-19. (2020). https://www.who.int/news/item/27-04-2020-who-timeline 